\section{BONE MINERAL DENSITY: AN ANALYSIS OF WEIGHT BEARING, RESISTANCE AND IMPACT PHYSICAL ACTIVITIES}

KEY WORDS: Bone Mineral Density, Static Resistance Weightbearing, High-impact Weightbearing And No Impact No Weight-bearing.

\section{Dr. Arvind Malik* Dr.(Mrs.) Sonia Malik}

\section{Dr. Vishal Dahiya}

Professor, Department Of Physical Education, Kurukshetra University, Kurukshetra, Haryana, India. *Corresponding Author

Associate Professor, Department Of Physical Education, Arya Girls College, Shahabad(M), Kurukshetra, Haryana, India.

Assistant Professor, Department Of Physical Education, Hindu College, Sonipat, Haryana, India.

Studies have confirmed that resistance training can have a beneficial effect on bone mineral contents. But, it is not well established that which type of sporting activity is more beneficial for increased bone mineral density (BMD). The objective of the study was to find out the difference in the BMD between various sporting activities. As a part of study, bone mineral density of elite sportsmen belonging to various type of sports in respect to weight bearing, resistance and impact were compared. Research design for present study was a cross-sectional design. A total of 120 elite sportsmen (mean age $=22.14$ years, mean $B M I=24.89 \mathrm{~kg} / \mathrm{m} 2$ ), who have won first $/$ second/third position at least at national/ interuniversity levels in the discipline of Weight lifting ( $\mathrm{N}-22)$, Volleyball ( $\mathrm{N}-24)$, Basketball ( $\mathrm{N}-24)$, Athletics (Long distance, Middle distance and Cross-Country runners) (N - 25) and Cycling ( $N-24)$ participated in the study. Bone mineral density was measured by using Ostepro-ultrasound bone mineral density system. The ANOVA results revealed statistically significant difference between different groups for right and left leg Calcaneal Bone Mineral Density $(\mathrm{g} / \mathrm{cm} 2)$ with $F$ value of $9.14(\mathrm{p}<0.01)$ and $8.38(\mathrm{p}<0.01)$ respectively, indicating that there exists a significant difference in the BMD between various groups. Further, when BMD was compared between sportsmen of various categories with weightlifters for right leg Calcaneal Bone Mineral Density, the t value was significant (Volleyball, Basketball, Athletics and Cycling the t-value was 18.20, 20.29,14.06 and 21.76 respectively). Similarly, t value was significant (Volleyball 15.92, Basketball - 20.44, Athletics - 10.09 and Cycling -21.64) when left leg Calcaneal Bone Mineral of weight lifters were compared with other categories. It is concluded that bone mineral density is higher in sportsmen who participate in higher static resistance weight-bearing in comparison to high-impact weight-bearing and no-impact no weightbearing.

\section{INTRODUCTION}

The World Health Organisation, Osteoporosis comes second to cardiovascular disease as a global health problem. Osteoporosis has affected approximately over 200 million people around the world. In India, population of people with osteoporosis or low bone mass is around 50 million Kaushal et al. (2018). Due to osteoporosis, more than 4.5 million Indian women above the age of 60 years suffered fracture spine and more than 250,000 people sustain a hip fracture every year Mehta et al. (2020). Similarly, in the European Union (EU) total number of fragility fractures is projected to increase from 2.7 million in 2017 to 3.3 million in 2030; an increase of $23.3 \%$ Borgström et al. (2020). Physical activity is a main factor necessary for maintaining bone mass, whereas physical inactivity being a potential cause of bone loss Buehlmeier et al. (2017). Thus, reduced physical activity due to the COVID19 stay-at-home order may affect bone health in general population as well as patients with osteoporosis.

Bone health and fracture risk are also dependent on many other factors, beside physical activity, the daily intake of calcium and vitamin $D$ is very important. According to International Osteoporosis Foundation report (2009) nearly all Asian countries fall far below the FAO/WHO recommendations for Calcium intake of between 1,000 and $1,300 \mathrm{mg} /$ day. In Asian population the median dietary calcium intake in the adult is approximately $450 \mathrm{mg} /$ day, with a potential detrimental impact on bone health in the region. Hip fractures are becoming a matter of concern in Asia particularly because of a 2-3 times increase in their incidence in almost every country in the continent Patel et al.(2016).

Animal studies have demonstrated a significant relationship between mechanical loading and bone formation. In humans, physical exercise, especially weight bearing activity has been reported to have beneficial effects on the skeleton in both adolescent and the elderly Scerpella et al. (2003). Bone mineral density has been demonstrated to be higher in male athletes than in less active individuals Pettersson et al. (1999). Additionally, athletes especially those who are strength trained, generally have greater bone mineral density than non-athletes, and that maximum strength levels and muscle mass correlates with bone mineral density Chilibeck et al. (1999).

Exercise programs can be classified as static weight-bearing exercises (e.g., single-leg standing), high-impact weightbearing exercises (e.g., jogging, running, dancing, jumping, and vibration platform), low-impact weight-bearing exercises (e.g., walking and Tai Chi), high-impact nonweight-bearing exercises (e.g., progressive RE), low-impact non-weight-bearing exercises (e.g., swimming and cycling) and combination exercises Howe (2011). Evidence shows that exercise may help build and maintain bone density at any age. To stimulate the osteogenic effects for bone mass accretion, bone tissues must be exposed to mechanical load exceeding those experienced during daily living activities. Of the several exercise trainings programs, resistance exercise ( $R E$ ) is known to be highly beneficial for the preservation of bone and muscle mass Hong \& Kim (2018). Studies have seen bone density increase by doing regular resistance exercises, such as lifting weights, two or three times a week. This type of weight bearing exercise appears to stimulate bone formation, and the retention of calcium, in the bones that are bearing the load. The force of muscles pulling against bones stimulates this bone building process. Weightbearing exercises are the most effective to build bones. In the present study an attempt was designed to examine the bone mineral density of sports persons who are participating in wide range of weight bearing activities.

\section{Material and Methods}

A total 120 elite sports persons (mean age $=22.14$ years, mean $\mathrm{BMI}=24.89 \mathrm{~kg} / \mathrm{m}^{2}$ ), who have won first $/$ second/third position 
at least at national/ inter-university levels during the years of study in the different types of sports discipline in respect to resistance, impact and weight-bearing: higher static resistance weight-bearing - Weight lifting (N - 22), highimpact weight-bearing - Volleyball $(\mathrm{N}-24)$, Basketball (N 24) and Athletics (Long distance, Middle distance and CrossCountry runners) $(\mathrm{N}-25)$ and no-impact no weight-bearing Cycling $(\mathrm{N}-24)$ were examined for Bone Mineral Density (BMD). Calcaneal bone mineral density (cBMD) was used to determined quantitatively using the bone Sonometer. Bone Mineral Density (BMD) was measured with Ultrasound Bone Densitometer CM-200 manufactured by ELK CORPORATION Overseas Division, Tokyo.

\section{RESULTS}

Table - 1 Analysis of Variance (ANOVA) for Right leg Calcaneal Bone Mineral Density $(\mathrm{g} / \mathrm{cm} 2)$ in the Subjects of various categories

\begin{tabular}{|c|c|c|c|c|r|}
\hline $\begin{array}{c}\text { Source of } \\
\text { Variation }\end{array}$ & $\begin{array}{c}\text { Sum of } \\
\text { Squares }\end{array}$ & df & $\begin{array}{c}\text { Mean Square } \\
\text { Variance }\end{array}$ & $\begin{array}{c}\text { F- } \\
\text { Value }\end{array}$ & p \\
\cline { 1 - 5 } Between Groups & 11.17 & 4 & 2.925 & \multirow{2}{*}{9.14} & $<0.001$ \\
\hline Within Group & 37.32 & 115 & 0.32 & & \\
\hline Total & 48.42 & 119 & & \multicolumn{2}{|l}{} \\
\hline
\end{tabular}

Initially mean and standard deviation were calculated of different categories of sportsmen, later on, ANOVA and unpaired $t$ test was used to analyze the significant difference of BMD between sportsmen. Analysis of variance for the Right Leg Calcaneal Bone Mineral Density $\left(\mathrm{g} / \mathrm{cm}^{2}\right)$ in the subjects of various categories is $9.14(\mathrm{P}<0.001)$, it indicates that there exists significant difference within and between the all five categories of subjects for Right Leg Calcaneal Bone Mineral Density $\left(\mathrm{g} / \mathrm{cm}^{2}\right)$.

Table - 2 Significance of difference between means of Weight lifters and players of various sports categories for Right leg Calcaneal Bone Mineral Density $\left(\mathrm{g} / \mathrm{cm}^{2}\right)$

\begin{tabular}{|l|l|l|l|l|l|l|l|}
\hline S. No. & Categories & M1 & M2 & M.D & S.D1 & S.D2 & T value \\
\hline
\end{tabular}

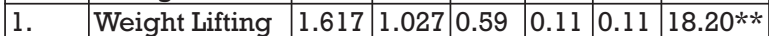
v/s Volleyball

\begin{tabular}{|l|l|l|l|l|l|l|l|}
\hline 2. & Weight Lifting & 1.617 & 0.929 & 0.68 & 0.11 & 0.12 & $20.29 * *$ \\
\hline
\end{tabular} v/s Basketball

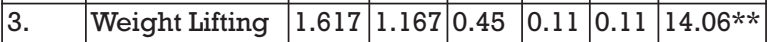
v/s Athletics

\begin{tabular}{|l|l|l|l|l|l|l|l|}
\hline 4. & Weight Lifting & 1.617 & 0.768 & 0.849 & 0.11 & 0.16 & $21.76 * *$ \\
\hline
\end{tabular} v/s Cycling

$* *$-Significant at 0.01 level

Further, $\mathrm{t}$ value as per table -2 indicates that Weight lifters were having Significantly better mean Right Leg Calcaneal Bone Mineral Density $\left(\mathrm{g} / \mathrm{cm}^{2}\right)$ in comparison to Volleyball, Basketball, Athletics and Cycling players as the calculated $t$ value was $18.20,20.29,14.06$ and 21.76 respectively.

Table -3 Analysis of Variance (ANOVA) for left leg Calcaneal Bone Mineral Density $(\mathrm{g} / \mathrm{cm} 2)$ in the Subjects of various categories

\begin{tabular}{|c|c|c|c|c|c|}
\hline $\begin{array}{c}\text { Source of } \\
\text { Variation }\end{array}$ & $\begin{array}{c}\text { Sum of } \\
\text { Squares }\end{array}$ & df & $\begin{array}{c}\text { Mean Square } \\
\text { Variance }\end{array}$ & $\begin{array}{c}\text { F- } \\
\text { Value }\end{array}$ & $\mathbf{p}$ \\
\cline { 1 - 5 } Between Groups & 10.71 & 4 & 2.68 & 8.38 & $<0.001$ \\
\hline Within Group & 36.91 & 115 & 0.32 & & \\
\hline Total & 47.62 & 119 & & & \\
\hline
\end{tabular}

As per table -3 , the F value is $9.40(\mathrm{P}<0.001)$ for the Left Leg Calcaneal Bone Mineral Density $\left(\mathrm{g} / \mathrm{cm}^{2}\right)$ in the subjects of various categories.

Table - 4 Significance of difference between means of Weight lifters and players of various sports categories for Left leg Calcaneal Bone Mineral Density $\left(\mathrm{g} / \mathrm{cm}^{2}\right)$

\begin{tabular}{|l|c|c|c|c|c|c|c|}
\hline S. No. & Categories & M1 & M2 & M.D & S.D1 & S.D2 & T value \\
\hline
\end{tabular}

\begin{tabular}{l|l|l|l|l|l|l|l|}
\hline l. & Weight Lifting & 1.611 & 1.022 & 0.589 & 0.11 & 0.14 & $15.92^{* *}$
\end{tabular} v/s Volleyball

\begin{tabular}{|c|c|c|c|c|c|c|c|}
\hline 2. & $\begin{array}{c}\text { Weight Lifting } \\
\text { v/s Basketball }\end{array}$ & 1.611 & 0.916 & 0.695 & 0.11 & 0.12 & $20.44 * *$ \\
\hline 3. & $\begin{array}{c}\text { Weight Lifting } \\
\text { v/s Athletics }\end{array}$ & 1.611 & 1.161 & 0.45 & 0.11 & 0.19 & $10.09 * *$ \\
\hline 4. & $\begin{array}{c}\text { Weight Lifting } \\
\text { v/s Cycling }\end{array}$ & 1.611 & 0.752 & 0.859 & 0.11 & 0.16 & $21.64 * *$ \\
\hline
\end{tabular}

**-Significant at 0.01 level

Further, $\mathrm{t}$ - value for Left Leg Calcaneal Bone Mineral Density $\left(\mathrm{g} / \mathrm{cm}^{2}\right)$ between the weight lifters and sportsmen of various Categories (Volleyball - 15.92, Basketball - 20.44, Athletics 10.09 and Cycling -21.64 ) is also significant.

\section{DISCUSSION}

As per the results, the weightlifters were found with significantly higher Calcaneal Bone Mineral Density (g/cm2) for both legs in comparison to players of various categories i.e. volleyball, basketball, athletes and cycling. The magnitude of mechanical load is important for bone formation, and resistance exercise elicits a magnitude of strain that exceeds the threshold required for increased bone modelling Frost (1987). Frost (2003) mechanical loading is a fundamental factor for bone mass accretion, this principle of the loading phenomenon is also known as the Mechanostat theory and was first developed by Frost. This model suggests that the bone possesses an inherent biological system to elicit bone formation in response to high mechanical strains, thereby strengthening the bone. This system involves the bone cells, mainly osteocytes, that can detect and respond to mechanical loading. Osteocytes play a key role in the remodelling process by sensing the mechanical loads, and transmitting the information to the osteoblasts and osteoclasts, which then maintain the skeletal homeostasis Klein-Nulend et al. (2013).

Sclerostin is a protein produced in osteocytes, which plays a central role in regulating the formation of bone. It functions as a Wnt antagonist, blocking the canonical Wnt/ -catenin signaling pathway.Wnt-signaling pathway leads to increased osteoprogenitor cell populations and decreased apoptosis of mature osteoblasts. Mechanical loading downregulates sclerostin expression in bones, thereby increasing osteoblastic bone formation and decreasing bone resorption by the inhibition of osteoclast activity Galea et al. (2017).

Bone formation is increased in regions of high strain, in particular, the periosteal bone surface, whereas bone turnover and porosity are reduced. Consequently, mechanical loading can lead to increase in the crosssectional area and tissue density of bones. In addition, this theory indicates that the skeletal effect of mechanical loading is site-specific, with greater response at skeletal sites where loading impacts are greater. The majority of weight-bearing exercise elicit physical loading to the lower limbs; as expected, positive skeletal effects on hip regions have been reported in previous studies and literature reviews Martyn-St James et al. (2009) and Bolam et al. (2013). Bone adaptation to mechanical loading affects not only the BMD but also geometric markers of bone strength Kukuljan et al. (2011).

To generate the adaptive response of bone (osteogenesis) to mechanical loading, sufficient magnitude, rate, and frequency of loading are necessary. Many animal studies showed that loading must be dynamic not static Lanyon \& Rubin (1984), induce high frequency strains O'Connor (1982), and be applied rapidly Rubin \& Lanyon(1985). Furthermore, because bone adapts to customary patterns of loading such as onedirectional movement, diversification of loading such as multi-directional training is required to stimulate an adaptive skeletal response Lanyon (1996). Exercise training could enhance bone strength, independent of changes in BMD, through alterations in bone structure and/or localized adaptation in bone distribution at the sites subjected to the 
greatest strain Allison et al. (2015). During exercise, an increase in cortical thickness due to load-induced periosteal apposition and, to a lesser extent, due to reduced endocortical resorption, will increase the resistance of a bone to bending Warden et al. (2014).

Recently there has been emerging and growing evidence that Vitamin D also protect against COVID-19 and to the severity of the disease. The plausible mechanisms include induction of cathelicidins and defensin proteins by vitamin $\mathrm{D}$ that can decreases the viral replication rates and COVID-19 related cytokine storm that produce the inflammation in lining of the lungs, leading to pneumonia Grant et al. (2020). Therefore, regular resistance exercise and proper supplementation of vitamin $\mathrm{D}$ in this global pandemic is very much essential for bone health and protection from COVID -19.

\section{CONCLUSION}

The studies done over last three decades, suggest that impact of physical exercise and sport training is an important factor in the acceleration and maintenance of bone mineral density. The present study has also demonstrated that sportsmen who are involved in higher weight bearing exercises are having better BMD. In conclusion, present study analysis reveals that sports activities involving high resistance and weight bearing has a positive effect on bone status. This implies that agerelated loss in bone mineral density is preventable by the appropriate weight bearing and resistance exercise program that includes increased mechanical loading with sporting activity of higher impact. Clinically, this information is important, as it can be utilized while designing preventive and treatment plans for osteopenic and osteoporotic individuals respectively.

\section{REFERENCES}

1. Allison SJ, Poole KE, Treece GM, Gee AH, Tonkin C, Rennie WJ, Folland JP, Summers GD, Brooke-Wavell K. The Influence of High-Impact Exercise on Cortical and Trabecular Bone Mineral Content and 3D Distribution Across the Proximal Femur in Older Men: A Randomized Controlled Unilateral Intervention.J Bone Miner Res.2015 Sep;30(9):1709-16.

2. Borgström F., Karlsson L., Ortsäter G. Fragility fractures in Europe: burden, management and opportunities. Arch Osteoporos. 2020;15(1):59. doi: 10.1007/s1 1657-020-0706-y.

3. Bolam KA, van Uffelen JG, Taaffe DR. The effect of physical exercise on bone density in middle-aged and older men: a systematic review. Osteoporos Int. 2013 Nov; 24(11):2749-62.

4. Buehlmeier J, Frings-Meuthen P, Mohorko N, Lau P, Mazzucco S, Ferretti JL, Biolo G, Pisot R, Simunic B, Rittweger J. Markers of bone metabolism during 14 days of bed rest in young and older men. J Musculoskelet Neuronal Interact. 2017 Mar 1; 17(1):399-408.

5. Chilibeck, P. D., Sale, J. T., Webber, J. C.. Exercise and bone mineral density. 1999 J.Sports Med., 19:103.

6. Frost HM. Bone "mass" and the "mechanostat": a proposal. Anat Rec. $1987 \mathrm{Sep}$ 219(1):1-9.

7. Frost HM.Anat Rec A Discov Mol Cell Evol Biol.2003 Dec;275(2):1081-101.

8. Galea GL, Lanyon LE, Price JS. Sclerostin's role in bone's adaptive response to mechanical loading.Bone. 2017 Mar;96():38-44.

9. Grant W.B., Lahore H., McDonnell S.L. Evidence that vitamin D supplementation could reduce risk of influenza and COVID-19 infections and deaths.Nutrients.2020;12(4):E988. doi: 10.3390/nul2040988.

10. Hong AR \& Kim SW. Effects of Resistance Exercise on Bone Health. Endocrinol Metab (Seoul). 2018Dec;33(4):435-444.doi: 10.3803/EnM.2018.33.4.435

11. Howe TE, Shea B,Dawson LJ, Downie F,Murray A, Ross C, Harbour RT, Caldwell LM, Creed G Cochrane. Exercise for preventing and treating osteoporosis in postmenopausal women. Database Syst Rev.2011 Jul 6; (7):CD00033.

12. International Osteoporosis Foundation The Asian Audit: Epidemiology, costs and burden of Osteoporosis in Asia 2009. [last cited in 2009]. Available from: http//www.iofbonehealth.org.

13. Kaushal N., Vohora D, Jalali RK, Jha S. Prevalence of osteoporosis and osteopenia in an apparently healthy Indian population - a cross-sectional retrospective study. Osteoporosis Sarcopenia. 2018 Jun;4(2):53-60. doi: 10.1016/j.afos.2018.04.002.

14. Kukuljan S, Nowson CA, Sanders KM, Nicholson GC, Seibel MJ, Salmon J, Daly RM. Independent and combined effects of calcium-vitamin D3 and exercise on bone structure and strength in older men: an 18-month factorial design randomized controlled trial.J Clin Endocrinol Metab. 2011 Apr;96(4):955-63.

15. Klein-Nulend J, Bakker AD, Bacabac RG,Vatsa A, Weinbaum S. Mechanosensation and transduction in osteocytes.Bone.2013 Jun;54(2):182-90.

16. Lanyon LE. Using functional loading to influence bone mass and architecture: objectives, mechanisms, and relationship with estrogen of the mechanically adaptive process in bone. Bone. $1996 \mathrm{Jan}$; 18(1 Suppl):37S-43S.

17. Lanyon LE, Rubin CT. Static vs dynamic loads as an influence on bone remodeling.JBiomech. 1984; 17(12):897-905.

18. Mehta N., Garg B., Malhotra R. Management of fragility fractures in India [published correction appears in best pract res clin rheumatol. Best Pract Res Clin Rheumatol.2019;33(2):301.309. doi: 10.1016/j.berh.2019.05.002.
19. Martyn-St James M, Carroll S. A meta-analysis of impact exercise on postmenopausal bone loss: the case for mixed loading exercise programmes. Br J Sports Med.2009 Dec; 43(12):898-908.

20. Rubin CT, Lanyon LE. Regulation of bone mass by mechanical strain magnitude. Calcif Tissue Int. 1985 Jul;37(4):411-7.

21. Patel MC., Chandra M. \& LO JC. Mortality following hip fracture in Chinese, Japanese, and Filipina women Am J Manag Care, 22 (2016), pp.e358-e359

22. Petterson U, Nordstrom P, Lorentzon R. A Comparison of Bone Mineral Density And Muscle Strength In Young Male Adults With Different Exercise Level. Calcif.Tissue International, 1999.64:490-498.

23. Suominen, H. Strength training for osteoporosis. Book of abstracts, 4th international conference on strength training. Aristotle University of Thessaloniki;2004.23-26.

24. O'Connor JA, Lanyon LE, MacFie $\mathrm{H}$. The influence of strain rate on adaptive bone remodeling.J Biomech. 1982; 15(10):767-81.

25. Warden SJ,Mantila Roosa SM, Kersh ME, Hurd AL, Fleisig GS, Pandy MG,Fuchs RK. Physical activity when young provides lifelong benefits to cortical bone size and strength in men. Proc Natl Acad Sci U S A. 2014 Apr 8; 111 (14):533742. 